\title{
MILK FATTY ACIDS FROM DIFFERENT HORSE BREEDS COMPARED WITH COW, GOAT AND HUMAN MILK
}

\author{
Maria Claudia Curadi ${ }^{1}$, Roberto Leotta ${ }^{1}$, Giovanna Contarini ${ }^{2}$, Mario Orlandi ${ }^{1}$ \\ I DPA, Pisa University, Viale Piagge 2, 56123 Pisa, Italy \\ ${ }^{2}$ CRA-FLC, Via Lombardo 11, 26900 Lodi, Italy \\ mccuradi@vet.unipi.it
}

\begin{abstract}
The essential role of fatty acids (FA) in human nutrition was widely documented. Since unsaturated fatty acids amount in mare milk seems to be higher than in cow milk, an approach was considered to evaluate differences between some equine breeds and compare fatty acids composition in different species. Trial was carried out on 30 Haflinger, 6 Noriker and 12 Thoroughbred milk samples collected at 30, 60 and 90 days from delivery. FA profile was investigated referring to linoleic (LA), $\alpha$-linolenic acid (ALA), LA/ALA ratio and saturated/unsaturated ratio. LA was higher in Thoroughbred milk at 30,60 and 90 days, ALA in Noriker mares versus Thoroughbred and Haflinger, underlining an interesting genetic characteristic. LA/ALA ratio was $0.51,0.49,0.39$ in Noriker at 30, 60, 90 days with a sat/unsat ratio about 1 . In Thoroughbred sat/unsat ratio was $0.87,0.71,0.57$; in Haflinger 1.24, 1.09, 1.28. Investigations concerned also milk FA from Haflinger, Noriker and Thoroughbred mares collected at 60 from delivery compared with cow, goat and human milk. Unsaturated FA were found about $55 \%$ in mare samples, higher than cow and goat (30-33\%) and similar to human. Sat/unsat ratio was lower than 1 in mare milk, about 2 in cow and 2.3 in goat. All mare samples were rich in LA (6.22-15.41\%) and ALA (7.09-12.50\%). In human milk LA and ALA were $13.54 \%$ and $1.02 \%$; lower in goat $(2.62 \%$ and $0.63 \%)$ and in cow $(1.86 \%$ and $0.57 \%)$. Sat/unsat ratio was between 0.70 and 1.09 in horses, 2.30 in goat, 1.88 in cow and 0.83 in human milk.
\end{abstract}

Key words: mare milk; horse breeds; milk fatty acids; linoleic acid; $\alpha$-linolenic acid

\section{МЛЕЧНИ МАСНИ КИСЕЛИНИ ОД РАЗЛИЧНИ РАСИ КОЊИ ВО СПОРЕДБА СО КРАВЈОТО, КОЗЈОТО И ХУМАНОТО МЛЕКО}

Есенцијалната улога на масните киселини (FA) во човечката исхрана беше широко документирана. Откако се констатира дека количината на незаситените масни киселини во млекото од кобила е повисока отколку во кравјото млеко, интересирањето беше насочено кон процена на разликите меѓу млекото на некои раси коњи и на споредба на составот на масните киселини во различните видови млеко. Експериментот беше извршен на 30 грла од расата хафлингер, 6 грла од расата норикер и 12 полнокрвни коњи, од кои беа земени примероци на млеко собрани на 30, 60 и 90 дена по породувањето. Профилот на масните киселини беше испитуван во однос на нивото на линолна (LA) и алфа-линоленска киселина (ALA), односот на LA/ALA и односот на заситени/незаситени масни киселини. Линолната киселина беше повисока во млекото од полнокрвните коњи на 30, 60 и 90 дена, алфа-линоленската киселина кај кобилите од расата норикер во споредба со полнокрвните и коњите од расата хафлингер, потцртувајќи интересна генетска карактеристика. Односот LA/ALA кај расата норикер на 30, 60, 90 дена беше $0,51,0,49,0,39$ со односот заситени/незаситени масни киселини околу 1 . Кај полнокрвните коњи односот заситени/незаситени масни киселини беше $0,87,0,71,0,57$; кај хафлингер 1,24 , $1,09,1,28$. Истражувањата се однесуваа исто така на споредба на млечните масни киселини од млекото на расите хафлингер, норикер и полнокрвните кобили, собрано на 60 дена по породувањето, со кравјото, козјото и хуманото млеко. Нивото на незаситените масни киселини беше околу $55 \%$ во примероците од кобилите, повисоко во однос на кравите и козите $(30-33 \%)$ и слично со хуманото. Односот заситени/незаситени масни киселини беше понизок од 1 кај кобилското млеко, околу 2 кај кравјото и 2,3 кај козјото. Сите примероци на млекото од кобилите беа богати со LA $(6,22-15,41 \%)$ и ALA $(7,09-12,50 \%)$. Во хуманото млеко LA и ALA беа $13,54 \%$ и $1,02 \%$; помалку кај козите $(2,62 \%$ и $0,63 \%)$ и кај кравите $(1,86 \%$ и $0,57 \%)$. Односот заситени/незаситени масни киселини беше меѓу 0,70 и 1,09 кај кобилите, 2,30 кај козите, 1,88 кај кравите и 0,83 кај хуманото млеко.

Клучни зборови: кобилско млеко; раси коњи; млечни масни киселини; линолна киселина; алфа-линоленска киселина 


\section{INTRODUCTION}

Fatty acids (FA) play an important role in human nutrition moreover by regulating several biological and methabolic processes. Dietary fat is a very important factor influencing human health, particularly cardiovascular diseases (Noble, 1999; Pikul and Wojtowsky, 2008). Health quality would really be improved not only by a general reduction in fat dietary intake, but with an accurate evaluation on saturated/unsaturated fatty acids ratio in favour of the latter (Noble, 1999). Equine milk's composition has been recently investigated because some characteristic proteic fractions suggested an utilization of this product, more similar to human milk than cow's, in diets to cow's milk allergic childrens (Businco et al., 2000; Curadi et al., 2001), in the opposite to what's happen with goat milk, where a certain cross-reactivity between cow and gaoat's milk has been demonstrated (Lucenti et al., 1999). Mare's milk and donkey's milk are also important for fat composition, particularly for fatty acids content, that they in fact play an important role in several biological processes; in medicine an increase of blood saturated/unsaturated fatty acid ratio is considered an important risk factor; long-chain polyunsaturated fatty acids (PUFA) are furthemore basic components of cellular membranes (Pikul and Wojtowsky, 2008; Csapò et al., 1995)

Equine milk seems to contain remarkable amounts of alpha-linolenic (ALA) and linoleic (LA) acids, usually called essential fatty acids (EFA) and respectively precursors of n-3 and n-6; they are much higher than in cow milk (Csapò et al., 1995), although its content of long-chain polyunsaturated fatty acids seems to be limited. LA and ALA are precursors of eicosanoids, whose imbalanced synthesis has also implicated in various pathological conditions including cardiovascular diseases and are considered cardioprotective factors. LA and ALA are not synthetized in the human body or are synthetized at such a slow rate, that they must be supplied by the diet. Infants may benefit from long chain polyunsaturated fatty acids unsupplemented formulae containing high ALA amounts, since recent studies (Clark et al., 1992) demonstrate that preterm infants are able to form arachidonic (AA) and docosahexaenoic acid (DHA). DHA can be synthetized by a complex series of chain elongation-desaturation reactions from ALA and plays an important function in infant nutrition, because of unusually concentrations found in their brain. Plasma DHA is available for developing brain and retina and is involved in dopamine and serotonine metabolism (Innis, 2000). A n-6 EFA deficit leads to an inflammatory skin condition both in animals and in humans; in atopic dermatitis a low blood EFA concentration was pointed out. Mare's milk fat content is lower compared to human and moreover dairy cows and FA composition showed smaller amounts of stearic and palmitoleic acids and higher quantities of oleic, linoleic and linolenic acids (Malacarne et al., 2002; Pellizzola et al., 2006). High FA unsatu$\mathrm{rated} / \mathrm{saturated}$ ratio, as found in equine milk, contributes to a lower fat melting temperature, higher iodine number and higher antimicrobial activity in comparison to cow milk (Lozovich. 1995).

Some previous work (Orlandi et al., 2002) evaluated FA amounts in the first months of lactation in Thoroughbreeds and Haflinger mares, considering mainly the changes on milk fat content due to the lactation period, as reported also by some other authors (Hoffman et al., 1998; Mariani et al., 2001; Doreau and Martuzzi, 2006); only a few numbers of studies concern the influence of lactation on fatty acids composition in equine milk (Csapò et al., 1995, Hoffman et al., 1998; Orlandi et al., 2002). Since unsaturated fatty acids amounts in mare's milk seem to be higher than in cow's milk, it was interesting to consider to study in detail an approach to evaluate differences between some equine breeds and compare fatty acids composition with cow, goat and human's milk samples.

\section{MATERIAL AND METHODS}

Mare samples from 30 Haflinger $(\mathrm{H}), 6$ Noriker $(\mathrm{N})$ and 12 Thoroughbred $(\mathrm{TH})$ pluriparious mares aged 5-9 years were collected at 30, 60 and 90 days from delivery. Haflinger and Noriker were located in the same breeding and were fed with the same pasture (Tab. 3) Thoroughbred come from a different breeding center and were mainly fed with hay and concentrate. We have also used in this trial samples from 5 Trotter $(\mathrm{T})$, and compared 60 days samples from all evaluated horse breeds with cow, goat and human 60 days pool samples and Literature values (Tab. 2). Every equine milk sample was obtained as a pool of two milkings before feeding time from every mare. All samples were frozen at $-20{ }^{\circ} \mathrm{C}$. FA composition was performed according to the Roese-Goettlieb extraction (FIL- 
IDF:1D-1996) by using capillary chromatographic investigation for methyl esters (FAME), with a HP 23 cis-trans polar column length $30 \mathrm{~m}$ (i.d. $32 \mathrm{~mm}$, d.f. $0.25 \mathrm{~mm}$ ) according to the FIL-IDF, 182-1999 method (CE Instruments GC 8000). Gas-chromatographic analysis was also carried out for animal feeds using $100 \mathrm{~m} \times 0.25 \mathrm{~mm}$ capillary column. To evaluate differences significatives at different collecting times Manova with repeated measures for LA and ALA was performed by JMP (SAS Inst., 1994),

\section{RESULTS AND DISCUSSION}

In the Table 1 we observe that LA was higher in Thoroughbred milk at 30, 60 and 90 days. In
Noriker samples ALA was always higher versus Thoroughbred and Haflinger, underlining an interesting genetic characteristic. LA/ALA ratio was $0.51,0.49,0.39$ in Noriker at 30, 60, 90 days with a sat/unsat ratio less than as average 1 . In Thoroughbred LA amounts were about $15-16 \%$ in all periods while ALA amounts were respectively $8.20,9.11,10.58 \%$ total $\mathrm{FA}$; sat/unsat ratio was $0.87,0.71,0.57$. In Haflinger samples the same was $1.24,1.09,1.28$.

Table 2 reports LA and ALA composition of different administered feed

Table 3 shows the results related to 60 days milk samples composition from 4 different horse breeds compared with cow, goat and human's.

Table 1

Linoleic acid (LA), $\alpha$-linolenic acid (ALA), LA/ALA and saturated/unsaturated ratio (SAT/UNSAT) at different sampling time (30, 60, 90 days from birth) in Thoroughbred (TH), Haflinger $(H)$ and Noriker $(N)$ milk samples

\begin{tabular}{lccc|ccc|ccc}
\hline \hline & \multicolumn{3}{c|}{30 days } & \multicolumn{3}{c|}{60 days } & \multicolumn{3}{c|}{90 days } \\
\cline { 2 - 10 } & $\mathrm{TH}$ & $\mathrm{H}$ & $\mathrm{N}$ & $\mathrm{TH}$ & $\mathrm{H}$ & $\mathrm{N}$ & $\mathrm{TH}$ & $\mathrm{H}$ & $\mathrm{N}$ \\
\hline LA & $15.06 \mathrm{a}$ & $9.89 \mathrm{~b}$ & $8.23 \mathrm{c}$ & $15.41 \mathrm{a}$ & $10.21 \mathrm{~b}$ & $6.22 \mathrm{c}$ & $16.29 \mathrm{a}$ & $8.60 \mathrm{~b}$ & $9.49 \mathrm{c}$ \\
ALA & $8.20 \mathrm{a}$ & $6.06 \mathrm{~b}$ & $15.82 \mathrm{c}$ & $9.11 \mathrm{a}$ & $7.09 \mathrm{~b}$ & $12.50 \mathrm{c}$ & $10.58 \mathrm{a}$ & $6.84 \mathrm{~b}$ & $24.14 \mathrm{c}$ \\
LA/ALA & 1.89 & 1,80 & 0.51 & 1.70 & 1.54 & 0.49 & 1.60 & 1.26 & 0.39 \\
SAT/UNSAT & 0.87 & 1.24 & 1.01 & 0.71 & 1.09 & 0.74 & 0.57 & 1.28 & 0.98 \\
FAT \% & 1.80 & 2.12 & 2.84 & 1.05 & 1.98 & 2.06 & 1.06 & 1.78 & 2.10 \\
\hline \hline
\end{tabular}

$\mathrm{a}, \mathrm{b}, \mathrm{c}=\mathrm{P}<0.05$

Table 2

LA and ALA (\% total FA) feed composition

\begin{tabular}{lccc|cc}
\hline \hline & \multicolumn{2}{c|}{ TH } & \multicolumn{2}{c}{ H, N } \\
\cline { 2 - 5 } & LA & ALA & LA & ALA \\
\hline Hay & 7.96 & 3.98 & - & - \\
Concentrate & 21.61 & 1.60 & - & - \\
Pasture & - & - & 5.01 & 9.16 \\
\hline \hline
\end{tabular}

Table 3

Linoleic acid (LA), $\alpha$-linolenic acid (ALA), LA/ALA and saturated/unsaturated (SAT/UNSAT) ratio at 60 days from birth in Thoroughbred (TH), Trotter $(T)$, Haflinger $(H)$ and Noriker $(N)$ samples and cow, goat, human (> 30 days from delivery) compared with cow, goat, human from Literature

\begin{tabular}{lcccccccccc}
\hline \hline & $\mathrm{TH}$ & $\mathrm{T}$ & $\mathrm{H}$ & $\mathrm{N}$ & $\mathrm{Cow}$ & Goat & Human & Cow $^{(1)}$ & Goat $^{(2)}$ & Human $^{(1)}$ \\
\hline LA & 15.41 & 17.95 & 10.21 & 6.22 & 1.86 & 2.62 & 13.54 & 1.60 & 1.03 & 13.00 \\
ALA & 9.11 & 8.39 & 7.09 & 12.50 & 0.57 & 0.63 & 1.02 & 1.80 & 0.32 & 1.40 \\
LA/ALA & 1.70 & 2.14 & 1.54 & 0.49 & 3.61 & 4.15 & 13.23 & 0.89 & 3.22 & 9.29 \\
SAT & 41.86 & 41.30 & 52.13 & 42.13 & 60.39 & 69.47 & 45.24 & - & - & - \\
UNSAT & 58.14 & 58.70 & 47.87 & 57.87 & 33.49 & 30.21 & 54.62 & - & - & - \\
SAT/UNSAT & 0.71 & 0.70 & 1.09 & 0.74 & 1.88 & 2.30 & 0.83 & - & - & - \\
\hline \hline
\end{tabular}

(1) Jensen et al. (1990), ${ }^{(2)}$ Zan et al. (2005) 
Unsaturated FA were found about $55 \%$ in mare samples, higher than goat and cow $(30 \%-$ $33 \%$ ) and similar to human. Sat/unsat ratio was lower than 1 in mare milk, 1.88 in cow and 2.30 in goat. All mare samples were rich in LA $(6.22 \%$ $15.41 \%$ FA) and ALA (7.09\%-12.50\%). In human milk LA and ALA were $13.54 \%$ and $1.02 \%$; LA values riched $13.0 \%$, ALA $1.40 \%$ from Literature (Jensen et al., 1990). Lower values were found in goat $(2.62 \%$ and $0.63 \%$ ); data from Literature (Zan et al., 2005) reported $1.03 \%$ and $0.32 \%$ respectively. Lower values were also found in cow samples (1.86\% LA and $0.57 \%$ ALA); $1.6 \%$ and $1.8 \%$ (Jensen et al., 1990). Sat/unsat ratio was between 0.70 and 1.09 in horses ( 0.81 as average), 2.30 in goat, 1.88 in cow and 0.83 in human milk.

\section{CONCLUSIONS}

Linoleic acid was significantly higher in Thoroughbred's milk at 30,60 and 90 days but very interesting amounts were also found in Haflinger and Noriker mares. Linolenic acid (ALA) was significantly higher in Noriker mares not only versus Thoroughbred but also versus Haflinger living in the same breeding and nutrition conditions, and so we suggest interesting genetic characteristics of those horse breed. These last conditions make LA/ALA ratio about $0.51,0.49$ and 0.39 in Noriker milk samples at 30,60 and 90 days of lactation with a saturated /unsaturated fatty acids ratio less than 1; in the other two breeds we observe a LA/ALA and saturated /unsaturated very interesting for human nurition. Mare LA and ALA amounts were generally higher than in goat and cow milk and total unsaturated FA levels were also higher. In human milk LA level resulted similar as in mare's while ALA was lower. Unsaturated FA and sat/unsat FA ratio appeared similar in human and equine milk and lower than saturated FA. In goat and cow samples saturated FA resulted predominant.

\section{REFERENCES}

[1] Businco, L., Giampietro P.G., Lucenti, P, Lucaroni, F., Pini, C., Di Felice, G., Iacovacci, P., Curadi, M. C., Orlandi, M. (2000): Allergenicity of mare's milk in childrens with cow's milk allergy. J. Allerg. and Clin. Immun., 105 (5): 1031-1034.
[2] Clark, K. J., Makrides, M., Neumann, M. A., Gibsonn, R. A. (1992): Determination of the optimal ratio of linoleic acid to alpha-linolenic in infant formula. J. Pediatr., 120: 151-158.

[3] Csapo', J., Stefler, J., Martin, T. G., Makray, S., Csapo'Kiss, Z. (1995): Composition of mare's colostrum and milk. Fat content, fatty acids composition and vitamin content. Int. Dairy J., 5: 393-401.

[4] Curadi, M. C., Giampietro, P. G., Lucenti, P., Orlandi, M. (2001): Use of mare milk in pediatric allergology. Proc. ASPA XIV Congress, 647-649.

[5] Doreau, M., Martuzzi, F. (2006): Fat content and composition of mare's milk. EAAP Pub., Nutrition and feeding of the broodmare, 120: 77-87.

[6] Hoffman, R. M., Kronfeld, D. S., Herbein, J. H., Swecker, W. S., Cooper, W. L., Harris, P. A. (1998): Dietary carbohydrates and fat influence milk composition and fatty acid profile of mare's milk. J. of Nutr., 128: 2708-2711.

[7] Innis, S. M. (2000): The role of dietary n-6 and n-3. Dev Neuosci., 22 (5, 6): 474-480.

[8] Jensen, R. G., Ferris, A. M., Lammi-Keefe, C. J., Henderson, R. A. (1990): Lipids of bovine and human milks: A comparison. J. Dairy Sci., 73: 223-240.

[9] Lozovich, S. (1995): Medical uses of whole and fermented mare milk in Russia. Cult. Dairy Prod. J., 2: 19-21.

[10] Lucenti, P., Giampietro P. G., Lucaroni, F., Plantamura, M., Curadi, M. C., Orlandi, M. Businco, L., (1999): Allergenicità del latte di cavalla, del latte di capra e di due formule idrolisate di latte vaccino in bambini con allergia alle proteine del latte vaccino. Inter. Congress on Paediatrics, Florence, 7-10 February.

[11] Malacarne, M., Martuzzi, F., Summer, A., Mariani, P. (2002): Protein and fat composition of mare's milk: some nutritional remarks with references to human and cow's milk: Int. Dairy J., 12: 869-877.

[12] Mariani, P., Summer, A., Martuzzi, F., Formaggioni, F., Sabbioni, A., Catalano, A. L. (2001): Physicochemical properties, gross composition, energy value and nitrogen fractions of Haflinger nursing mare milk throughout 6 lactation months (2001). Anim. Res., 50: 415-425.

[13] Noble, R. C. (1999): Animal supplies of omega - 3 fatty acids for human nutrition. Progr. in nutrition, 1 (3-4): 413.

[14] Orlandi, M., Goracci, J., Curadi, M. C. (2002): Essential fatty acids (EFA) in Haflinger and Thoroughbreed mare's milk. Ann. Fac. Med. Vet., LV: 319-325.

[15] Pellizzola, V., Contarini, G., Povolo, M., Giangiacomo, R. (2006): Chemical-physical characteristics and fatty acid composition of mare's milk. Milchwissenschaft, 61 : 33-36.

[16] Pikul, J., Wojtowsky, J. (2008): Fat and cholesterol content and fatty acid composition of mares's colostrums and milk during five lactation months. Livestock Sci., 113 (23): 285-290.

[17] Zan, M., Stibilj, V., Rogely, I. (2006). Milk fatty acid composition of goats grazing on alpine pasture. Sm. Rum. Res., 64 (1, 2): 45-52. 